\title{
The Human Body as a Mirror in Ottoman Literature ${ }^{1}$
}

\section{Özgen Felek ${ }^{2}$}

\begin{abstract}
Recently, scholars of Islamic studies have become increasingly interested in the human body. Yet, the literary appearance of the body in different genres has not been studied in detail yet. The present article aims to demonstrate that the Islamic tradition has employed the human body as a mirror that reflects visually and physically various concepts and aspects of human characteristics. This article scrutinizes various genres and written formats with a specific focus on the body as it appears in legal and literary texts that became best sellers in the Ottoman Empire, including hagiographical works, heroic narratives, physiognomy books, and romances. This includes not only the texts originally produced in Turkish, but also the widely known and read texts translated from Arabic and Persian into Turkish. These texts demonstrate the various ways that the body was used as a platform on which, and through which, certain values could be displayed. As we have seen, while legal texts understand the body as a mirror that reflects one's piety and/or sinfulness in both this world and hereafter, for literary genres the human body is a mirror through which one's good or bad personal traits, faith, sanctity, and heroism, as well as depth of love and capacity for sexuality, could also be physically witnessed.
\end{abstract}

Keywords: Islam, Ottoman Literature, human body, personality, piety, sanctity, heroism, love, sexuality.

\footnotetext{
'Walter G. Andrews, Kristina Richardson, İrvin Cemil Schick, Jamel Velji, and Travis Zadeh read the article at its different stages. I am very grateful to them for their excellent feedback and suggestions to improve it. I would like to dedicate this article to Guy Burak, a dear friend.

The sub-sections on sanctity, love, and sexuality are brief summaries of papers presented at the International Conference on the Hilyah in Islamic Tradition (Istanbul, May 2018); the International Colloquium New Perspectives on Gender Studies: Islamic Masculinities Past and Present (Barcelona, July 2017); From the Steppes to the Bosporus: A Celebration of Rudi Paul Lindner (Ann Arbor, April 2017); the ACLA Annual Meeting (Seattle, March 2015); and the Islamicate Occult Sciences Workshop (Princeton, February 2014).

Throughout the article, for the sake of simplicity and consistency, I have used the same diacritical marks for Turkish, Arabic, and Persian names, words, and book titles, with the exception of those which are quoted directly from published sources.

${ }^{2}$ The Department of Near Eastern Languages and Civilizations, Yale University, New Haven, CT. (ozgen.felek@yale.edu), Orcid: https://orcid.org/0000-0002-9746-325X
}

Makale Gönderilme Tarihi: 09.02.2019, Kabul Tarihi: 11.05.2019 


\section{Osmanlı Edebiyatında Bir Ayna Olarak Insan Bedeni}

Öz: Son zamanlarda, İslam üzerine çalışan araştırmacılar insan bedeni ile daha fazla ilgilenmeye başladı. Ancak, bedenin farklı türlerdeki edebi yansıması henüz ayrıntılı olarak çalışıımadı. Bu makale, İslamî geleneğin insan bedenini görsel ve fiziksel olarak çeşitli insanî özellikleri ve kavramları yansıtan bir ayna olarak nasıl kullandığını göstermeyi amaçlamaktadır. Makale, Osmanlı İmparatorluğu'nda popüler olan dinî ve edebî metinlerde ortaya çıktığı haliyle, menâkıbnâmeler, kahramanlık metinleri, kıyafetnâmeler, ve mesnevîler de dahil olmak üzere, bedene özel bir odaklanma ile çeşitli yazın türlerini ve yazılı formları incelemektedir. Bu, yalnızca Türkçe metinleri değil, Arapça ve Farsça'dan Türkçe'ye çevrilmiş bilinen ve çok okunan metinleri de içerir. Bu metinler, insan bedeninin belirli değerlerin gösterilebileceği bir platform olarak kullanılmasının çeşitli yollarını göstermektedir. Gördüğümüz üzere, dinî metinler insan bedenini hem bu dünyada hem ahirette kişinin dindarlığını ve/veya günahkârlığını yansıtan bir ayna olarak algılarken, edebî türler için insan bedeni kişinin iyi ya da kötü kişisel özelliklerinin, dindarlığının, kutsallığının, kahramanlığının, aşkta derinliğinin ve cinsel kapasitesinin de fiziksel olarak gözlemlenebileceği bir aynadır.

Anahtar Sözcükler: İslam, Osmanlı Edebiyatı, insan bedeni, kişilik, dindarlık, kutsalık, kahramanlık, aşk, cinsellik.

\section{Introduction}

In May 2012, Recep Tayyip Erdoğan, Turkey's Prime Minister at the time, equated abortion with murder, calling it an insidious plan to reduce Turkey's population. Party legislators immediately proposed a law to outlaw abortion after the fourth week of pregnancy, the only exception being to save the mother's life. Thousands of women responded by filling the streets, crying out, "My body; my choice!" Ali Maraşlıgil, a theologian and scholar, responded against the women's protest shortly afterwards, stating "That body is not yours; it is a trust from God!"

Maraşlıgil's claim was not radical. In fact, it expounded on the perception of the human body that is found in Islamic legal texts, which understand the human body as a trust given by God, and therefore sacred and to be honored. These texts regulate not only a human being's relationship with God and other beings but also, and even more importantly, with his/her own body. Indeed, control of one's body is limited by certain rules described in the hadith accounts: the body must be kept as close as possible to its original state through cleansing and care taking. The Prophet advised his companions to clean their armpits, groin, and nails to prevent the accumulation of dirt, to keep their teeth and noses clean, to wash and comb their hair, and to trim their beards and mustaches, especially the part that hung from their lips to prevent the unpleasant sight of food touching facial hair (Ad-Dimashqi, 2003: 192). 
The most obvious examples of bodily regulations are strict bans on tattoos, on having aesthetic surgery to "fix" a body part to make it more attractive, and on plucking eyebrows. All such alterations are seen to interfere with God's preference and gift. The only allowed operation or bodily marking, or one could say alteration to the body, is male circumcision. All Muslim men are expected to be circumcised. Those who convert to Islam later in life, even at a very old age, are still obliged to be circumcised. This requirement is linked to the story of Abraham who, according to tradition, circumcised himself at the age of 80. Therefore, it would not be wrong to state that one common characteristic that all Muslim men share, regardless of their ethnic, social, cultural, and educational backgrounds, is circumcision. Traditionally, this ritual marking of the body, whether for a boy or a newly converted Muslim man, is announced and celebrated publicly as a symbol of his Muslim-hood.

Furthermore, individuals are not allowed to display their bodies as they wish. The legal texts clearly state when, to whom, and what parts of the body can be displayed to others. Men, for example, are not allowed to display their bodies to other men between the navel and the knee. ${ }^{3} \mathrm{~A}$ Muslim woman's dress code is described as covering all parts of the body except for the face, hands, and feet. The Qur'an mandates the wearing of an hijab and modest clothing (Qur'an, 24:30-31), although some argue that it is not a strict requirement, but merely a strong suggestion (and is one that is open to individual interpretation) (Barlas, 2002: 152-160).

A human body is sacred even after death, as is clearly expressed in the hadith account that "Breaking the bone of a dead person is similar (in sinfulness) to breaking the bone of a living person." Therefore, to pull out a corpse's teeth, to cut out a body part, or to burn it is also forbidden (Aramesh, 2009; Keskin, 2009). Even after death, a person does not have the right to decide what to do with his/her own corpse: cremation, for example, is considered to be strictly illicit. Before burial, the corpse should be washed and cleaned, and following prayers, it should be buried facing Mecca. It cannot be buried naked; rather, it should be dressed with a piece of white cotton fabric --other kinds of fabrics are not allowed (Halevi, 2007).

One might ask then, if we do not own our bodies, what is our relationship with it and with the bodies of others? ${ }^{4}$ Recently, scholars of Islamic studies have

\footnotetext{
3 On the topic of which areas men have to cover, see the hadith accounts, for example, Ebû Dâvûd, "Libâs," 37; Dârekutni, 1, 230, 231; Müsned, III, 478.

4 John Hospers offers a list for a basic distinction between one's body and the bodies of others. John Hospers, An Introduction to Philosophical Analysis, second edition (London: Prentice Hall, 1967), 405-406. Theories of the body are relatively vast, and will not be repeated here. In this regard, see for example Shahzad Bashir's Sufi Bodies: Religion and Society in Medieval Islam (New York: Columbia University Press, 2011), 13-18; and F. J. Callard's "The Body in Theory" in Society and Space (1998) 16:3, 387-400. For the feminist approaches to the notion of the body, see Lennon, Kathleen, "Feminist Perspectives on the Body," The Stanford Encyclopedia of Philosophy (Fall 2014 Edition), Edward N. Zalta (ed.), URL= <https://plato.stanford.edu/archives/fall2014/entries/feminist-body/>. Also, James Giles, "Bodily Theory and Theory of the Body" in Philosophy, Vol. 66, No. 257 (Jul., 1991): 339-347.
} 
also become increasingly interested in the human body. In the Introduction to his pioneering work, Scott Kugle discusses in detail the Sufi understanding of corporeality in South Asian and Moroccan Sufism (Kugle, 2007). Fuad Khuri explores the cultural meanings of the body in terms of "body ideology" and "body language" in Arab-Islamic culture (Khuri, 2001). Shahzad Bashir likewise analyzes how the body was represented and embodied in Persian Sufi literature between 1300 and 1500 CE (Bashir, 2011). Through the concept of "aha ("Ar., blight, or damage"), Kristina Richardson examines disabilities and body ascetics in the medieval Islamic world (Richardson, 2012). In addition to these very influential works, there is a vast broader literature that increases our understanding of the place of the human body in Islam. ${ }^{5}$

The present article aims to demonstrate that the Islamic tradition has employed the human body as a mirror that reflects visually and physically various concepts and aspects of human characteristics, namely personality, piety, sanctity, heroism, love, and sexuality. Although they overlap occasionally, different traditional and literary genres focus on diverse concepts. It is thus necessary to scrutinize a large body of literature, starting from the earliest days of Islam, to really tease out the various portrayals of the body. In what follows, I consider various genres and written formats with a specific focus on the body as it appears in legal and literary texts that became best sellers in the Ottoman Empire, including hagiographical works, heroic narratives, physiognomy books, and romances. This includes not only the texts originally produced in Turkish, but also the widely known and read texts translated from Arabic and Persian into Turkish.

First, I will scrutinize physiognomy books that trace personal characteristics through the physical features of the body. Second, using the hadith collections and mi rāc-nāme books (the books of ascension of the Prophet), I will outline the signs of piety and sinfulness. Third, drawing from the kııșașu'l-enbiyā ("the stories of the prophets") narratives, which are dedicated to the biographies and miracles of the Qur'anic prophets, the şemāoil-nämes, the hilyes (the genres that relate bodily features of the Prophet Muhammed and other holy figures), and menākıı-nāme (hagiographical narratives), I will look at how sanctity is displayed on the body of holy figures. The narratives demonstrate that it was not only holy bodies, but also regular human bodies, that were employed to prove ones' sacredness. Fourth, I will examine narrative heroic biographies, such as cenk-nāmes (the book of battle), to see if one's heroic features can be traced through bodily signs. Finally, I will analyze gazels (lyrics), mesneviss (romances), and erotic texts as well as physiognomy books to demonstrate the signs of love and sexuality on one's body.

\footnotetext{
5 For a brief summary on the human body in Islamic perception, see Valerie J. Hoffman, "Islamic Perspectives on the Human Body: Legal, Social and Spiritual Considerations" in Embodiment, Morality, and Medicine. Theology and Medicine Book Series, eds. Cahill L.S., Farley M.A. Vol 6. Springer, 1995, 37-55.
} 


\section{Personality}

A well-known hadith account states, "Verily, Allah does not look at your appearance or wealth, but rather he looks at your hearts and actions (Sạhịh. Muslim, 2564)." The physiognomists, however, paid great attention to people's physical features, claiming that a person's personality could be deduced through his or her physical appearance. Since physiognomists understood the body and mind as being knitted together like one single entity, the body was a venue and a tool through which the inner personality could be reached.

These books provide a manual that taught people how to trace personal characteristics through the body's static and movable features. They focus on four particular aspects: color, shape, voice, and manner, offering general explanations for each. For example, they scrutinize the color of the skin, the shape of the nose, or the size of hands, and then posit what the variances in each signified (Çavuşoğlu, 2004: 12). In doing so, these manuals construct a generic, gender-neutral body, and relatively vague descriptions that can be applied to both genders, as in the following description of lips, the most visible and apparent feature of the body. The size, shape, and color of the lips are all given great importance as the indicators of an individual's good or bad character:

One whose lips protrude like that of a negro is wicked and stupid. Muḥy al-Dīn Ibn 'Arabī in his work, Kitābu't-tedbīrāt-i ilāhiyye says, "If such a person's lips are quite red, it is an indication of his having a balanced character!" The same point is made in the work entitled Şerh̆-i Külliyāt. One whose lips are large and who has a protruding lower lip, like-those of a camel or a donkey, is dull-witted and ignorant. Very pale lips denote sickness and phlegm. The person whose lips have turned a very dark colour suffers from melancholy. People whose lips are drawn at the corners, with a drooping lower lip, are extremely stupid. If a person's lips are so narrow and short that his teeth protrude, this indicates that he is of a robust and strong physique. One who has well-proportioned red lips makes sound judgements (Seyyid Loḳmān Çelebi, 1987: 17/15r).

Muḥyī'd-dīn 'Arabī (d. 1240), mentioned here, was a twelfth/thirteenthcentury Andalusian Sufi mystic and philosopher. Our author, Seyyid Loḳmān, a court historian during the reign of Murād III (r. 1574-1595), wrote this work during the second half of the sixteenth century in Istanbul. His reference to the earlier authors demonstrates how understanding of the body was re-created, yet remained little changed, over the centuries in different geographical regions.

Since body parts are pieces, not a composite whole, no past can be associated with them. Likewise, since the physiognomy texts deal with the nonindividualized parts of non-identifiable bodies, to physiognomists, a person's 
social, cultural, and religious background has little bearing on their personal traits. Despite their general lack of individualization, to some physiognomists ethnic background and race is important to consider as well (Mustafa bin Bâlî, 2014: 229-234, 373-379; Ta'likîzâde Mehmed Subhî, 2016:12r-24V). One of the key exceptions to these points would be the royal physiognomy book prepared for sultan Murād III. In 1579, five years after he was enthroned, Murād III was presented a physiognomy book titled Ḳıyāfetü'l- insāniyye fĩ şemā 'ili'l- 'Oșmāniyye ("Human Physiognomy Concerning the Personal Dispositions of the Ottomans") by Seyyid Lokmann, the court historian noted above. The preparation of such a text for Murād, the twelfth Ottoman sultan, is particularly significant. It is through certain physical characteristics that the author creates a fixed and idealized image of an Ottoman sultan in the readers' minds.

Although most of the entries in the physiognomy books seem to be nongendered, there are certain entries on particular body parts that specifically indicate a male body, such as mustaches and beards. For the most part, these texts ignore the female body, their main purpose not being to distinguish between female and male bodies, but rather between male bodies. It is in these texts that one could find the idealized male body according to cultural aesthetic norms of the time. The following entry, for example, demonstrates the function of beards on the male body:

A sparse beard or no beard at all denotes high intelligence and understanding. A sparse beard is also a sign of good nature and kindness; a long beard, of lack intelligence; a thick beard, of dejection and evil intention. An excessively sparse beard, commonly called a Tartar's beard (Ṭațäri beard) signifies an evil temper, but a moderately thick and long beard is a token of dignity and sagacity (Seyyid Loḳmān Çelebi, 1987: 18/14V-15r).

Numerous physiognomy books appeared in Ottoman Turkish. ${ }^{6}$ What follows exemplifies how certain personality traits were traced through one's body parts in the four Ottoman physiognomy books, namely Ta liḳi-zāde Meḥmed Șubhī’s Firāset-nāme ("The Book of Physiognomy”) (1574), Mușțafá bin Bālī’s Risāle-i Kiyāset-i Firāset ("The Book of Physiognomy”) (1575), Enverī's Kıyāfet-nāme ("The Book of Physiognomy"), and Seyyid Loḳmān Çelebi's Kıyāfetü'l- Insāniyye fĩ Şemā 'ili'l- 'Oșmāniyye (1579). ${ }^{7}$ Despite slight differences,

\footnotetext{
6 The Islamic world had been familiar with this genre from the ninth century on. In this regard, see Fabrizio Bigotti. Physiology of the Soul: Mind, Body, and Matter in the Galenic Tradition of the Late Renaissance (1550-1630) Forthcoming: Brepols, 2018. Ali Çavuşoğlu, Kıyafet-nameler. Istanbul: Akçağ, 2004. Emin Lelic. "Physiognomy ('ilm-i firāsat) and Ottoman Statecraft: Discerning Morality and Justice." Arabica 64 (2017): 609-646. Swain (S.) (ed.) Seeing the Face, Seeing the Soul. Polemon's Physiognomy from Classical Antiquity to Medieval Islam. With contributions by Boys-Stones George, Elsner Jas, Ghersetti Antonella, Hoyland Robert and Repath lan (Oxford: Oxford University Press, 2007). For a comprehensive list of the physiognomy books and the secondary sources in Turkish, see Müjgân Çakır's "Kıyâfet-Nâme'ler Hakkında Bir Bibliyografya Denemesi."

7 Mustafa Bin Bâlî. Risâle-i Kiyâset-i Firâset; Ta'likîzâde, Firâset-nâme; Enverî’s Kıyâfet-nâme is located in Manisa Manuscript Library, no: 1506/1, under the title "Kıyāfetnāme." Kıyāfetnāme Numūne-i Enverī, eds. Bekir
} 
these sixteenth century texts repeat essentially the same relationships between certain body parts and one's personality, since our authors use the same sources.

Although these texts trace both merits and bad habits through the features of particular body parts, bad habits receive more attention. Indeed, authors' main stress seems to have been to help their readers recognize badnatured people. The positive features that mostly appear in these texts can be listed as good morals, intelligence, happiness, generosity, loyalty, bravery, and courage. Of them, bravery and courage are discussed briefly below as indicative of possible heroic behaviors. Nevertheless, according to physiognomists, whether a person has good morals or not can be known from his straight back. A short beard is a sign of intelligence, empathy, and comprehension; small feet are a sign of happiness; and long fingers are a sign of thoughtfulness, carefulness, and talent in art. Thin and moderate eyebrows signify easy comprehension. A neck with moderate features is a sign of moderateness. If one's arms extend to the knees, this is a sign of nimbleness, heroism, and generosity. An open forehead with moderate wrinkles indicates truthfulness, loyal friendship, and skillfulness.

The significance of a body's shape can be better understood through the hilye texts, a specific genre dedicated to the description of the Prophet Muhammed's body and personality. Most of these texts commenced with a statement that all of God's creatures were created in the most beautiful form, but the Prophet Muhammed was the most beautiful and perfect of all. Based on descriptions reported by his companions and transmitted by 'Alī, his cousin and son-in-law, the hilye texts describe Muhammed as follows:

His blessed forehead was wide. His blessed beard was rounded. His blessed beard was partially auburn. His blessed eyes were black. Some said: He had hazel eyes. Some said: They seemed white. Some said: They seemed yellow. He had a small space between his eyebrows. He had thin eyebrows. His words were sweet. His blessed teeth were widely set. His blessed nose was noble. He had light brown skin. His blessed eyes were black. His blessed ears were small. His blessed veins were fine. His blessed face and his blessed beard were round. His blessed forehead was wide [sic]. His blessed hands were long. His blessed height was proportionate. His blessed feet were medium. His blessed fingers were thin. His blessed body had no hair. There was a line stretching from his blessed chest down to his blessed navel. There was a seal of prophethood between his shoulders. The seal of prophethood was written on his navel (Hilye-i Nebeviyye, $1 \mathrm{v}-2 \mathrm{r}$ ). 
This suggests that, in the physiognomy books at least, the Prophet Muhammed's physical appearance appears to underlay the construction of an idealized body. That is, the moderate size of everything is always the best.

While positive features seem to have been agreed upon by the various authors, unique negative features appear in the different texts. Emphasis on the negative traits such as falsehood, deceitfulness, untruthfulness, cowardice, anger, jealousy, envy, lust, stinginess, avarice, idiocy, arrogance, ambition, laziness, dumbness, and ignorance suggests a general and widespread concern regarding individuals with such personalities. All can be traced through different parts of the body. Both a forehead with no wrinkles and a long forehead are noted as the signs of skittishness or empty talking, for example. Likewise, a midsized nose is a sign of a liar and one who talks a lot with no substance, while a large nose indicates that one has either anger issues or is immature. A deep voice also signifies a person who has anger issues. Our authors pay particular attention to the indicators of foolishness, saying that big, wide, or twitchy eyes, a big nose, a long neck, long beards, and tall height are all sure signs of foolery. Big and wide eyes, big and bulgy eyes, or black eyes are also signs of laziness, idlehood, jealousy, laziness, and unreliability. Long eyebrows that reach the corner of the eyes, as well as a hairy torso, are signs of dumbness and ignorance. Physiognomists further elaborate that, if a person's ears are too big, he is 256 ignorant; if they are too small, he is stupid and a thief. Eye color was tied to personality, as Kristina Richardson has written about the stigma of blue eyes in pre and post-Islamic Arab folklore in detail (Richardson, 2014: 13-29). The physiognomists note that blue eyes are indictors of viciousness and a generally bad personality; the texts also add red eyes to the list as defects that indicate bad morality.

Not only one's personal traits, but also his psychological state, such as anxiety, melancholy, or love can be known by looking at his body. Bushy eyebrows indicate an unclear mind overcome by love and melancholy; teeth that extend the mouth are signs of lacking emotions.

As we have seen, then, in creating a link between the body's physical traits and a person's personality, physiognomy books are general manuals. They do not individualize the bodies they describe, since they do not consider the body as a whole. Instead, they look at certain body parts. Therefore, if one desires to learn about someone's inner world, he needs to look separately at each entry for each body part, and in the end, put together all these pieces to construct a fuller picture of the person. It is, in a sense, like putting together randomly altered puzzle pieces. It is the reader's task to place each puzzle piece in order to create an individualized picture. While the physiognomy books deconstruct the body, the user of these manuals reconstructs it by putting these pieces together himself. 
Islamic literature is much more specific, though, in talking about the physical, bodily signs that indicate more spiritual features such as piety and sanctity.

\section{Piety}

Islam understands faith ("imān") as a matter of the heart. Yet, Muslims are expected to display their faith visibly. Islamic legal texts present the body as a tool through which people fulfill their required prayers and physically demonstrate what is in their hearts, as the five pillars of Islam indicate. The five pillars are: declaring the oneness of God, which new converts must do verbally in the presence of two witnesses; praying five times daily; fasting during the month of Ramadan; giving charity; and making a pilgrimage to Mecca at least once in a lifetime. Worship requires the participation of both body and soul; to one extent or another, all mandatory prayers involve the body, which in turn serves as a canvas by which to publicly display one's faith. Even though faith resides in the heart, then, it achieves visibility through bodily actions. This means that the body functions as a platform on which faith is displayed.

Physical prayer rituals are regulated without distinguishing gender; although the body's condition is taken into consideration, no one who is sane, conscious, and sufficiently healthy is exempted from their obligatory prayers. For example, disabled people and patients have the same obligation to daily prayers, albeit with accommodations made for what their bodies allow them to do.

Just as one's piety is displayed on the body, so is his/her sinfulness. For example, the Qur'an dictates that "[As for] the thief, the male and the female, amputate their hands in recompense for what they committed, as a deterrent [punishment] from Allah. And Allah is Exalted in Might and Wise" (Qur'an, 5:38). The hand of the thief is cut off; an adulteress is stoned or whipped (Mâverdî, 1976: 251-271). These punishments are public displays of disobedience to Divine law, meant to communicate the gravity of such sins. In his work Discipline and Punish that traces the development of the modern prison system, Michel Foucault states that such public punishments mark the victim (in our case, "the sinner"):

... either by the scar it leaves on the body, or by the spectacle that accompanies it, to brand the victim with infamy; even if its function is to 'purge' the crime, torture does not reconcile; it traces around or, rather, on the very body of the condemned man signs that must not be effaced; in any case, men will remember public exhibition, the pillory, torture and pain duly observed (Foucault, 1979: 34).

Bodily punishment serves to discourage other people from engaging in similar sins, since the whole punished body is visible to all. While corporal punishment creates a direct connection between the sin and the organ via which 
the sin (or crime) was performed, this validates their publicity; sexual sins are not in fact punished via sexual organs, perhaps because they are not available to others' direct observation.

The body's function as a platform for piety also appears in teachings regarding the hereafter. Not only in this world, but even after one's death, the body still displays belief and piety or disbelief and sinfulness. Since prayers are physically performed through the body, the results of those prayers are reflected on the body, as are otherworldly rewards and punishments. It is stated that faces of those who pray regularly will shine like a ray of light, suggesting that the body acts as a physical manifestation of piety on Judgment Day (Qur'àn 75:22, 80:38, 83:24). According to hadith accounts, believers will be recognized immediately through their faces and limbs shining as the traces of ritual cleansing:

"... on the Day of Resurrection... I will recognize my ummah from among the other nations." A man said, "O Messenger of Allah, how will you recognize your ummah from among the other nations from Nooh (Noah) to your ummah?" He said, "Their faces and limbs will be shining with the traces of wudoo and no one but they will be like that (Al-Ashqar, 2005: 232-234).

Believers are promised the reward of Paradise, which the hadith and commentary literature depicts as a place where the human body will be free from certain burdensome bodily functions, such as urination, defecation, and sweating (Al-Ashqar, 2002: 282). Furthermore, the people of Paradise will be embodied at the age of 33, "in the most perfect and beautiful form, in the image of their father Adam;" neither will experience aging (Al-Ashqar, 2002: 266-267).

Just as those in Paradise will be rewarded through their bodies, people who end up in Hell will be punished likewise through their bodies. The Qur'an warns and threatens the disbelievers that they will be Hell's fuel: "If you cannot do this, and you never will, then beware of the Fire prepared for the disbelievers, the fuel of which is man and stones" (Qur'an, 2:24). Whether one is bound for Hell or Paradise on Judgment Day will be clear especially from his or her face. While the inhabitants of Paradise are marked by their radiant and shining faces, the inhabitants of Hell will have black faces as the sign of their condemnation to Hell. ${ }^{8}$ They will be blind and deaf (Qur'an 17:97); their ears and noses will be severed; their faces will be beaten by the guardians of Hell (Qur'an 8:50, 47:27). As Christian Lange writes, "The Qur'an is a good deal more interested in the bodies of the damned than in those of the blessed in paradise." (Lange, 2016: 46)

\footnotetext{
8 For a thorough study on the eschatological images of the face, see Christian Lange, "On That Day When Faces Will Be White or Black' (Q3:106): Towards a Semiology of the Face in the Arabo-Islamic Tradition," in the Journal of the American Oriental Society, (127)4, 429-445.
} 
The descriptions both of Hell and of the ways the body will be burnt are elaborated further in the Hadith accounts. Based on these accounts, a fourteenth-century Mi 'rāc-nāme (The Book of Ascension) by an anonymous author from Herat depicts corporal punishment vividly through text and illustration. During his ascension to the Heavens, the Prophet is first taken to Hell by Gabriel to witness the state of sinners and unbelievers; while there, he sees "shameless women," so labeled by the anonymous author of the text, who have allowed strangers to see their hair. This hair, in turn, becomes the vehicle of their punishment: in Hell, such women are suspended by their hair. The author refers to Qur'anic verses that require women to lower their eyes, be chaste, hide their adornment except what appears thereof, and cover their breast. The author's narrative is accompanied by an illustration of such women in Hell. He likewise discusses (and illustrates) women who mock their husbands and leave home without their husbands' permission (being hung by their tongues and hair), or who commit adultery (being hung up from their hair and breasts) (The Miraculous Journey of Mahomet Mirâj Nâmeh Bibliothèque Nationale, 1977: 59; 59v). (Figure 1)

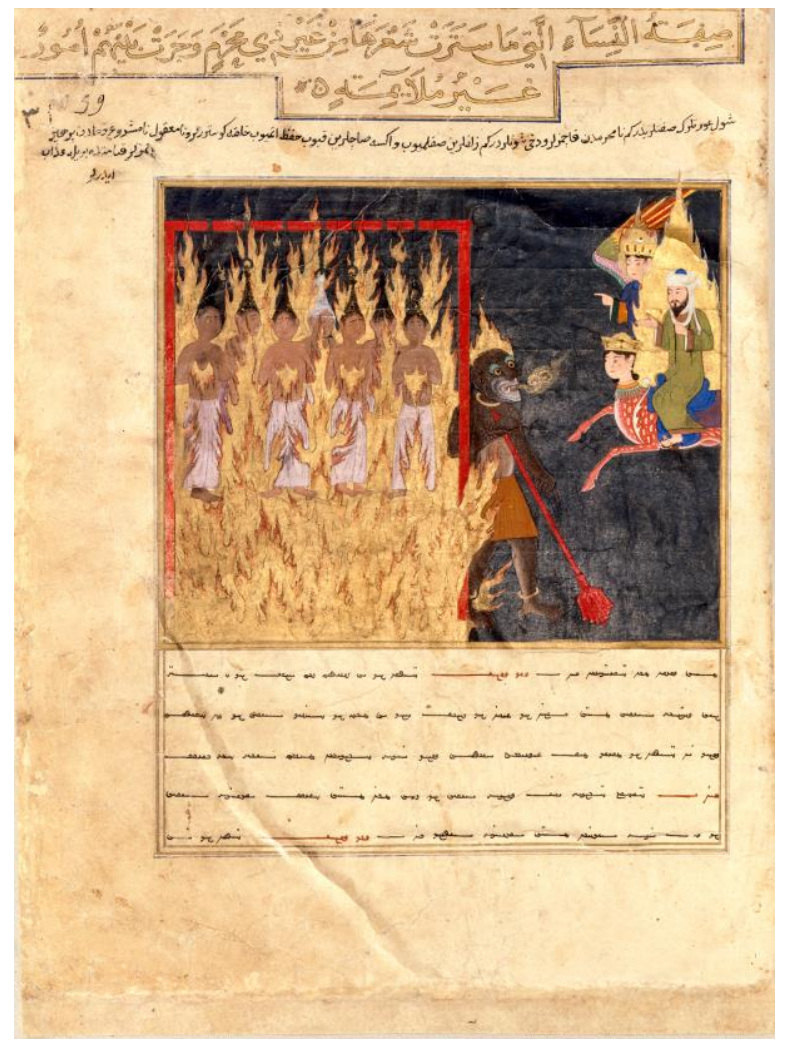

Figure 1. Mi rāc-nāme, fol. 59.

Bibliothéque Nationale, Manuscript Supplement Turc 190. 
Another group of Hell residents is hung by their necks as punishment for failing to give a tithe of their wealth during their lives. Those who bear false witness are given the head of a pig and an ass's tail, shown sticking out their long tongues to cool their thirsty lips dried out by the scorching fire of Hell. As our anonymous author further elaborates, large hooks come out of their mouths (The Miraculous Journey of Mahomet Mirâj Nâmeh, 1977: 63-65).

When God has finished His judgment of His people, He takes whomever He wills out of Hell through His mercy, ordering the angels to remove from the Fire all those who testified (in the world) the oneness of God. The angels of Hell will recognize those who used to pray in the world by the marks of prostration on their foreheads (the Fire of Hell consumes the entire body except this mark of prostration, because Allah has forbidden it to destroy this physical mark of piety). ${ }^{9}$

In life and in death, then, the faithfulness of pious Muslims is both enacted through and marked physically on their bodies. This faithfulness, in turn, protects their bodies from Hell and ensures their ascension to Heaven, where they will forever live whole and unblemished. It is not just faithfulness that is considered in this way, however; the bodies of the most holy and saintly persons were further marked as distinct from the rest of the faithful.

\section{Sanctity}

Islamic literature is replete with stories of the supernatural skills of certain individuals chosen by God. Like piety, holiness and Divine selection are most vividly proven through remarkable signs on a holy person's body. While prophetic and saintly bodies are portrayed with some physical characteristics that distinguish them from more common figures, their bodies are also set as the platform through which they perform their miracles. The miraculous deeds of holy people can thus be analyzed in two forms: the miracles that they perform on their own bodies, and the miracles that they perform on other people's bodies.

Although some significant and honorable figures in the Islamic tradition are women, the Qur'an specifically names only the men as prophets. The Ash'ariyye school acknowledges that women can be prophets; yet to the majority of Ehl-i Sünnet, prophethood is only endowed on men, to the exclusion of women, due to the latter's role as mothers and the requirement that prophets convey their message to the public. Reflecting patriarchal expectations, it is argued that a woman's attention and responsibilities to her children and her menstrual cycles, inherently limit both her prayers and daily life (Özarslan, 2006: 112; Barlas, 2002: 93-128).

\footnotetext{
9 Sahih Bukhari, Vol. 9, Book 93, Number 532C; Sahîh Muslim, Kitâb al-Imân, Bâb ar-Ru'yah, 1/299, no. 182.
} 
Male figures chosen as God's messengers are described as having the essential attribute of infallibility. Just as infallibility refers to the prophets' protection from all types of sins, their bodies likewise appear in the most perfect shape without any disability or defect. They are, in other words, in perfect physical form. The only exceptions are Moses, who is reported to have an occasional stutter, and Jacob, who temporarily lost his sight due to his excessive crying for Joseph. Although these two are depicted with minor defects, Moses' stutter was healed after he received his prophecy, while Jacob's temporary blindness was healed after he rubbed Joseph's shirt over his eyes (Qur'an, 12: 9296).

The Qur'an and Hadith accounts only briefly depict the prophets' miraculous bodies; their miraculous birth stories, physical descriptions, struggles with their people, and miracles are further detailed in the kıșașu'l-enbiyā, the biographies and miracles of the prophets. Anecdotes regarding their physical marks can be also found in other literary genres. In particular, the şemā'il-nāme and the hilye texts, which focus on the physical features and personalities of the prophets, have played a significant role in emphasizing these men's physically distinguishing marks used as proof of their prophethood.

The epitome of immediate evidence for one's holiness and difference is Abraham, who is distinguished through the light that emanates from his body (Hindî Mahmûd, 2013: 350-351). The ultimate evidence for his specialness comes from an episode in which King Nemrūd orders him to be thrown into a fire. Yet, the fire does not harm Abraham's body by the command of God: "O fire! Be coolness and safety upon Abraham" (Qur'an 21: 69). Although the Qur'an ends the story there, it was enriched upon through the narratives of storytellers, preachers, and poets. In his K়ıșaș-ı Enbiyā, for example, Maḥmūd Ḥindī details how the pit of fire was turned into a rose garden. By contrast, the bodies of infidels who accidentally touched the fire were immediately burnt, perhaps in reference to the Islamic teachings that unbelievers will be thrown into Hell (Hindî Mahmûd, 2013: 346-347; 350-351).

While Abraham's unburnt body is seen as evidence of his sacredness, to some Sufis, the exceptional beauties of Adam, Joseph, and Muhammed are perceived as their most significant characteristics (Murata, 2017: 101-128). It is thanks to his beauty that Joseph is defined as the "Embodiment of Half of the Beauty of the Entire Universe." According to mystics, when God decided to create human beings and the universe, He placed half of all beauty in the entire creation, He granted the other half to Joseph (Tarlan, 1964: 265). As the paragon of beauty, Joseph's magnificence is highlighted in the famous story in which he was sold to an Egyptian named 'Azìz. According to the story, 'Azīz takes Joseph home to adopt him as a son, however, his wife falls in love with and attempts to seduce Joseph. When she realizes her passion for Joseph is heard in the city, she invites the aristocratic women (who gossiped about her saying that she was of 
easy virtue) to her house in hope that they would understand her feelings. When Joseph steps in the room, the women are greatly amazed at his beauty. They cut their hands with their knives, exclaiming, "God save us! This is no mortal man! This is nought but a noble angel!” (Qur'an, 12:31).

The body's physical evidence of holiness is also used in the story of Moses' prophecy. Islamic tradition holds that magical performances were highly appreciated during Moses' era, and that he himself used miraculous acts to impress his opponents. ${ }^{10}$ The Qur'an states that Moses was given nine evidences (Qur'an, 17: 101), and one of these nine evidences is his white hand, known as the yed-i beyżà (Qur'an, 7: 108). When he was challenged by the Pharaoh to outperform the court magicians, Moses pulled out his hand out of his pocket; emanating the Divine light, this hand filled the audience with awe. Indeed, his hand gleamed to such a degree that the entire universe was filled with Divine light, even burning the infidels who were present there (Hindî Mahmûd, 2013: 528-529; 544).

According to Islam, the Prophet Muhammed was the last in the long line of prophetic figures. He is associated with the Nūr-ı Muhammedi (The Light of Muhammed), also known as Hakikat-i Muhammediye, which is believed to be a blessing, a truth that represents the spiritual figure of the Prophet (Rubin, 1975; Gruber, 2009). Not surprisingly, his body appears as the most marked among all prophets in order to emphasize his being the final one. He was reportedly born already circumcised, a highly significant feature given the importance of circumcision among the Abrahamic commands; being born with this act already completed indicates that he is of direct Abrahamic lineage (Kister, 1994).

The other evidence for his sanctity is his birthmark, a large mole on his back. Interestingly, while moles were seen as signs of the devil in early modern Christian Europe, Veronique Dasen has demonstrated that moles were interpreted as a sign that a body is prophetic since ancient times (Dasen, 2015). While Muhammed's light is described as an indication of his place in the prophetic lineage, having been carried from Adam to Muhammed, the hatmü'nnübüvve (the seal of prophecy) emphasizes the idea that God perfected and closed the door to prophecy by sealing it with Muhammed through his mole. The Qur'an states that Muhammed is the messenger of God and the last of the prophets (Qur'an, 33:40), yet the mole is only detailed in hadith. The hatmü'nnübüvve is physical proof of him being a true messenger of God with hadith descriptions of its size, shape, and place on his back or shoulders. ${ }^{11}$

In his well-known story, ỉbn İsḥāḳ relates how a Christian monk, named Bahīrā, accepted this mole as physical evidence of Muhammed's prophetic

\footnotetext{
${ }^{10}$ Within the Judaic tradition, Mūsā is described as having leprosy, and the story of White Hand is used to show his miraculous healing. In contrast, the Islamic version of the story dismisses the story of leprosy, keeping his body perfect and healthy. See, Exodus 4:6-8.

11 See, for example, Sahih Bukhari 7.574; Sahih Bukhari 4.741; Sahih Bukhari 1.189; Sahih Muslim 4.5793.
} 
status. As ibn İshāk tells, the Prophet used to travel with his uncle when he was a child. During a trip to Syria, Bahīrā identified him, having studied old manuscripts and been waiting for a prophetic figure to come during his time (Bahkou, 2015). While the caravan was passing by, Bahiirā noticed a cloud overshadowing Muhammed specifically and separately from other people. He also noticed the tree that lowered its branches over the caravan to provide further shade. He immediately realized that an extraordinary person was traveling in this caravan, so he invited them to come and eat with him. The story continues as follows:

When the people had finished eating and gone away... Bahiirā began to ask him [Muhammed] about what happened in this (T.. waking and in his) sleep, and his habits, and his affairs generally, and what the apostle of God told him coincided with what Bahīan knew of his description. Then he looked at his back and saw the seal of prophethood between his shoulders, in the very place described in his book (The Life of Muhammad a Translation of Ishāq's Sirat Rasūl Alläh with Introduction and Notes by A Guillaume, 2012: 80).

As soon as he saw "the seal of prophethood," Bahirā realized that Muhammed was the awaited prophet. In addition to this mole, Muhammed appeared to perform miracles through his body. Cābir bin 'Abdu'llāh narrates how water flowed from the Prophet's fingers when he and his followers did not have enough water:

I was with the Prophet and the time for the 'Asr prayer became due. We had no water with us except a little which was put in a vessel and was brought to the Prophet. He put his hand into it and spread out his fingers and then said, "Come along! Hurry up! All those who want to perform ablution. The blessing is from Allah." I saw the water gushing out from his fingers. So the people performed the ablution and drank, and I tried to drink more of that water (beyond my thirst and capacity), for I knew that it was a blessing. The sub-narrator said: I asked Jabir, "How many persons were you then?" He replied, "We were one-thousand four hundred men." (Bukhari, Book 7: Volume 69: Hadith 543)

Like the prophets, the preeminent Sufi bodies are also depicted as perfect in shape and form, a stage for the display of holiness and Divine intimacy. However, perfection is not the only shared aspect of the Sufi bodies and the prophetic bodies. Except for a few female sufis (i.e. Rābi 'atü'l-'adaviyye, an eight-century female Sufi), the numerous hagiographical narratives are dedicated mainly to the male Sufis. Their physical appearance is described in the way their disciples are affected by their charismatic appearance. Similarly, Sufi bodies are free from disability and deficiency. Most of them are defined as 
seyyids, the direct descendants of the Prophet, which inherently dismisses any possibility for physical deficiency and establishes the holiness of these figures.

Hagiographical texts function to sanctify individuals whom the Qur'an does not recognize as prophets or messengers of God, attributing to them certain distinguishing marks, physical characteristics, and saintly miracles. An anecdote in the Velāyet-nāme of Hācī Bektaş Velī, a 15th-century saintly figure of Anatolia, is one of the most striking hagiographical narratives, linking Hăci Bektaş Velĩ directly to 'Alī and the Prophet.

When the Sufis of Khorasan visit Şeyh Loḳmān-ı Perende to congratulate him on his pilgrimage, they notice a new fountain. Lokmān-ı Perende explains that this fountain is the miraculous deed of Hăcī Bektaş. Loḳmān-ı Perende's response surprise these saints, since Hācī Bektaş is only a small child. In awe, they ask him to show evidence of his sainthood:

Looking at [him], the Sufis of Horāsān said, "This is a child yet. Where did he receive such sainthood?" The key of the gate of wisdom, that is Hācī Bektaş-ı Velī, opened his blessed mouth [and responded], "I am the lion of the Lord of the universe; the pedigree of that wine-pourer of paradise [referring to the Prophet Muhammed]; and the secret of 'Alī, who is the essence of sainthood and the leader of the believers. Such sainthood and miracles have come to me as part of [my] inheritance. It is not surprising to see such signs in our pedigree since this is our portion from God." Having heard that, the saints of Horāsān said, "If you are indeed the secret of 'Alī, the shah of the heroes, show us your signs; [so that] we confirm you [as the descendant of 'Alī]. Hażret-i Hünkār Hāaī Bektaş the saint (may God sanctify his secret) asked them, "Do you know what the sign of Hażret-i 'Alî is?" They replied, "One of 'Alî’s signs is that there was a green mole radiating from his blessed palm." Hażret-i Hünkār Hācī Bektaş the saint (may God sanctify his secret) opened his blessed palm [and] showed [them]. They saw the beautiful, green mole radiating from his blessed palm. Then they said, "There was a beautiful, green mole radiating from his ['Alī's] blessed forehead as well." Hażret-i Hünkār revealed his forehead. The aforementioned mole was there on his forehead (Velâyetnâme, 2007: 9v-10r).

That Hācī Bektaş shows his palm and forehead with no surprise and question when he is asked to prove his sanctity and sainthood through a physical sign on his body, and the Sufis' immediate belief in and approval of Hācī Bektaş's sainthood, shows that it is not surprising to early modern readers to confirm and prove one's holiness through bodily marks. 
Bodily marks maintained their evidentiary role for holiness in later periods as well, as can be seen in the letters of the Ottoman sultan Murād III, who was a disciple of the Halveti master Şücā' Dede. Upon his submission, Sultan Murād began sending dreams and mystical experiences in letter form to his master. In these letters, compiled at the dawn of the second Islamic millennium $(\mathrm{H}$. 1001/1592), Murād appears to have portrayed himself as the awaited Messiah. In a way, the letters serve as evidence of his holiness and even of his being the Pole of Poles, the highest rank in the spiritual hierarchy. Among numerous letters, the following is particularly significant for our purpose here, for it attempts to confirm Murād's holiness through his body. Just as the Prophet is shown the situation of people in Paradise and Hell during his accession, so too is Murād. First, he hears a voice from God that invites him to the otherworld:

"Show Paradise and Hell to my servant [Murād]! Let him see what I have prepared for my servants in Paradise and Hell so that he informs my other servants." Upon saying this, they showed this poor one the levels of Paradise and Hell, the rewards for the pious people, and the tortures for the rebellious ones. There were people divided into groups burning in Hell. Naked [with no protection], I walked through the flames, but with the help of God, no harm came to me. And I returned to the Earth and laid down on my bed. Yet, I was reciting the name of God and shaking (Kitāb-ı menāmāt, 43r-43v).

This dream account is also significant as it functions to establish the Sultan as a blessed friend of God whose body is protected from the fire, just like the Prophet Abraham's. Furthermore, the holiness of these prophets' bodies is proven by their non-decayed state after death. The tradition holds that the bodies of prophets and saints do not become decayed. One of these nondecayed holy bodies is that of Arap Baba, a saintly figure and Seljuki commander who came to Eastern Anatolia to conquer Harput in the thirteenth century. A non-decayed body in a glass cabinet is still on display in Harput (Elazığ) as evidence of Arap Baba's holiness (Oymak, 2013).

The prophetic and saintly figures perform miracles not only through their own bodies, but also through those who suffer from physical deficiencies or health problems. Healing leprosy, epilepsy, blindness, and madness are among the most common miracles that can be found in the biographies of prophets and saints. The Qur'an recounts how Jesus heals the blind and the leper (Qur'an, 3:49). Similar to the Gospels of Matthew (17:14-20), Mark (9:14-29), and Luke (9:37-43) that narrate how Jesus cast out the evil spirit from a boy with epilepsy 
who has just had a seizure, thereby curing him, ${ }^{12}$ a hadith account details how Muhammed heals the cause of epilepsy (Ibn Kathir, 2001: 76)..$^{13}$

The hagiographical narratives are replete with such miraculous healing stories as well. The hagiographer of Şeyh Üftāde (d. 1580), an Ottoman mystic, relates the following well-known story regarding a woman who suffer from epilepsy. A man visits the Şeyh a few times to ask him to pray for his wife's remedy. The Şeyh gives him a piece of paper, tells him to take that paper to a certain location, and instructs him to draw a circle and sit inside it. The man does as the Şeyh instructs. While sitting inside the circle, he sees a mighty monarch approaching with numerous soldiers. The monarch reins in his horse and asked the man what he wishes for. After conveying the greetings of the Shaykh, the man submits the paper to this "Shah." After reading the message, the latter commands his soldiers to bring the "black" cripple jinn who is the cause of the epilepsy and kill him. When he is killed, the jinn turns into a dead snake, and the woman recovers from her illness (Menâkıb-ı Hazret-i Üftâde, 1996: 29-31). The hagiographer thus demonstrates the spiritual power of the Shaykh by healing and transforming the bodies of the seen and unseen creatures to establish his protagonist as an established saint.

Another saintly miracle relating a transformation story is related by the hagiographer of Hācım Sulțān, the foremost successor of Hācī Bektaş. The saintly power of Hāàm Sultān empowers him to easily change the sex of a young girl. While he wanders in the villages of Menteşe, in southwestern Anatolia, he stops in a small village to spend the night at the house of the most prestigious man in the village-a wealthy man with a daughter. Yet, the man refuses to invite Hācım Sultān to his house, saying that he has hosted many Sufis and begged them for help to have a son. He has spent his money on this hope, but is still unable to find a true Sufi who could help him, and thus he has a daughter, not a son. Out of disappointment, since the man refuses to host or honor any more Sufis, Hācım Sulțān and his disciples are left on the street with no place to go. In the end, Hācım Sulțān decides to visit the man, despite the man's views. Arriving at the man's house, he stretches his hand toward the door, saying, "In the name of God, the most gracious, the most merciful." The door opens on its own. The man's daughter is lying on her bed. Hāàm Sulțān approaches her, and passes his hand over her from head to toe, praying for her at the same time. At that moment, the girl's female organs are transformed into male organs. The hagiographer confirms that the man is happy with this miracle, and his daughter, now a son blessed by Hācım Sulțān, agreed to be his disciple (Velâyetnâme, 2007: $137 r-138 r)$.

\footnotetext{
${ }_{12}$ Matthew, 17:14-20; Mark, 9:14-29; and Luke, 9:37-43. The New Oxford Annotated Bible with the Apocrypha: Revised standard version, containing the second edition of the New Testament and an expanded edition of the Apocrypha (Eds. Herbert G. May, Bruce M. Metzger). (New York: Oxford University Press, 1977).

${ }^{13}$ Hafidh Abi Al-Fada'ah Ismail ibn Kathir, Book of Evidences: The Miracles of the Prophet (P. B. U. H.) (Trans. Ali Mwinyi Mzima and Ibn. R. Ramadhan) (Al-Mansoura: Dar al-Gad, 2001), 76. Quoted from Musnad Imam Ahmad, vol. 1, 268.
} 
In addition to healing the sick, transforming bodies, and changing one's gender, the protection of others' bodies from aging is also narrated as evidence of a man's holiness. An oft-quoted hadith account reports that one day the Prophet wanted to drink water, and Ebū Zeyd 'Amr ỉbn Ahțab el-Enșārī of Benī Hazrec brought a glass of water for him. When Ebū Zeyd 'Amr noticed a piece of hair floating in the water, he removed it. Witnessing this gesture, the Prophet prayed for him, patting Ebū Zeyd 'Amr's face and saying "O God, beautify him [Ebū Zeyd 'Amr], and keep his beauty." It is reported that Ebū Zeyd 'Amr lived for 120 years, but his face did not age, nor did his hair and beard turn gray. ${ }^{14}$ In a similar manner, Ottoman sultan Murād III wrote a Divine Inspiration that occurred in his heart, saying "Whoever looks at your blessed face, indeed the fire of Hell is forbidden to harm him. O the beloved of God!" This ability to protect others from physical harm aims to further establish him as a saintly figure (Kitāb-ı menāmāt, 30v).

The holy people do not make changes only to human or jinni bodies. There are also anecdotes regarding their spiritual ability to give life to inanimate things. The Qur'anic stories of Abraham and Jesus with the birds are two such narratives that demonstrate the power of the prophets to touch the souls of those who seek reassurance and satisfaction for belief and proof:

And when Abraham said: 'O my Lord, show me how You give life to the dead.' He said, 'Do you not then believe?' He said, 'Yes indeed but to satisfy my own heart.' He said, 'Take four birds and cut them into pieces. And then place a portion of them on every mountain. Then call them. And they will come to you in flight and know for certain that Allah is All-Mighty. All-wise (Qur'an, 2: 260).

While İbn Kesīr's Kıșașu'l-enbiyā elaborates on this verse that Abraham did as he was commanded, he emphasizes that Abraham's request was not caused by doubt. Rather, it was a desire "to watch it by his own eyes and go from the stage of the certainty of knowledge to the stage of the certainty of vision" (Ibn Kathir, 2003: 182). Ibn Kesï's explanation reflects pre-modern believers' need for visible and concrete evidence, and the role that the body plays as an easily accessible and visible form of evidence. The most popular interpretation of this verse is that Abraham was ordered to take these birds, to physically cut them into pieces, and to place each of these pieces on separate mountains. When Abraham called to them, Allah caused their parts to be rejoined and refilled with pulse and life. They then flew to Abraham with a speed that showed no sign of trauma -no sign that they had just been dismembered and scattered. And in this way did God show His prophet how He gives life to the dead. Abraham did not have doubt, he had certainty that Allah gives life and causes death; what he wanted to know was "how" Allah gives life to the dead.

\footnotetext{
${ }^{14}$ Tirmizî, Menâkıb 6; Ahmed ibni Hanbel, Müsned, Vol. 77, 341. íbn-i Ebi Şeybe Müsned, 316-327.
} 
What he sought was thus a higher level of certainty that directly engaged his heart and eyes.

While Abraham cuts the birds into pieces and brings them back together, Jesus gives life to a piece of clay, which then becomes a live bird when he blows into it (Qur'an, 5: 110). The fact that such miracles are named "clear proofs" (beyyināt) and "signs" (āyet) in other Qur'anic verses demonstrates how their power and ability to bring about physical change on bodies are perceived and used as concrete evidence of prophets' sanctity (Qur'an, 3:49; 5:110). The physicality of certain bodies can also point to their heroic status.

\section{Heroism}

In the Garib-nāme, one of the most important works nourishing popular religious mystical culture in the fourteenth century, 'Āşı ̣aşa (d. 1333) provides a detailed and straightforward definition of alp, a term used to describe brave Turkish warriors. Accordingly, alp-hood required nine essential elements: a solid heart, strong muscles, determination, (a special kind or especially elaborate or militaristic clothing) attire, a horse, a bow and arrow, a sword, a dagger, and a beloved. To 'Āşıḳ Paşa, strong muscles are an essential characteristic of a heroic man, just as they have been traditionally considered features of heroic figures in the physiognomy books. In studying the heroic bodies of Islamic literature, the physiognomists offer noteworthy insight. They claim to trace the heroic nature of individuals through their body's physical features: a thick, short, hairy neck like a lion; an open chest; a wide back; big and fleshy feet with lots of veins; eyebrows that are close to the eye; a big and wide mouth; a long, bony nose; a deep, strong voice; thick hair; and short height are all defined as the indicators of courage and bravery. Men embodying these features are more likely to have a heroic personality. The authors of these physiognomy books further elaborated that if a man's arms extend to his knees, this too is a sign of nimbleness and heroism.

The physiognomists offer more than just potential heroic traits and attitudes: they also address the lack of necessary features to act heroically. Thin fingers and small ears are signs of cowardice, for example, while constant blinking is a sign of fear. Likewise, these authors list a narrow back and missing teeth as indicators of weakness.

Even so, the texts dedicated to the significant Muslim heroic figures do not always portray their protagonists as muscular figures with large mouths or long, bony noses as outlined by the physiognomy authors. For example, in the cenk-nāme (the book of battle) narratives 'Alī's physical features are left vague. What follows is a relatively detailed description of 'Ali that is seen rarely in the texts:

He was of medium height. His chest was flat, and he had hazelcolored eyes [ala göz] ... he had a thick beard ... and he had a big 
belly, and whenever he looked at infidels' faces, they would get scared and shake like an autumn leaf, and with that blessed body, he would not eat for three, four, five days. There were times that he would not eat for seven, eight days (Şemseddin Sivasi, 2017: 460461).

However, this relatively detailed description given in the above passage from the Menäḳı-ı Çehär-yār-ı Güzīn does not appear in the narratives titled the Cenk-nāme, in which 'Alī is called Şāh-ı Merdān ("The Sultan of Men”). Instead, in these latter works his heroic nature is implied through his other features, namely his success in numerous battles and fights. While his physical appearance is not portrayed in detail, what he does with his body and with his voice is described fully. For example, when he shouts, his voice shakes the earth and skies (Demir and Erdem, 2007: 55/43r). He breaks down the doors of palaces, shakes the walls, and sometimes even causes earthquakes due to the sheer power of his voice:

... While sitting, Pādişāh-ı 'Āḳ said, "O şāh, what a strong earthquake it was!" Şāhin Şāh responded, "I am afraid 'Alĩ is breaking down the door of the palace." Pādişāh-ı 'Āḳ said, "O Şāh, what a strange fool you've become! 200 men cannot move this palace's door. Besides, Kahrımān- I Kătil built this palace. Who is 'Alī that he can break down this door on his own?" Şāhin Şāh replied, "You don't know 'Alī. First, see the door!" While they were in such conversation, Şirr-i Hudā ["The Lion of God"] pushed it once and shouting "O, Allāh!" he broke down the door and threw it away on his second try. Yet, such a move occurred within the palace that many walls got cracked. Those within the palace thought it that a part of the palace collapsed to the ground. Then, the Şāh-ı Merdān (the shah of men) entered [the palace], pulling out his [sword] Zü'l-fiḳār and walked to the throne. That night, the Şāh-ı Merdān saw who was alive and who would walk to him [to fight] despite 'Alī's awe. The Şāh-ı Merdān saw Şāhin Şāh and 'Alī sitting on the throne. While they were looking around, saying this and that got cracked, Hażret-i 'Alī let out such a yell of heart and soul that sounds echoed like a tiled bowl inside the palace. Due to this shout [of 'Alī], Şāhin Şāh lost his mind and fell on the ground on his face (Demir and Erdem, 2007: 130/194V-195r).

Similarly, the legendary epics do not describe the body of Hamza, the Prophet Muhammed's heroic uncle, in detail either. In the Hamza-nāme, a fifteenth-century text that includes 150-200 stories in fifty to sixty binders, Hamza is not depicted as a tall, large man; yet he is still a threat to his enemies and unbelievers. While the author largely ignores his physical appearance, all the living creatures in nature are amazed by Hamza's warrior-hood and combat skills (Sezen, 1991: 51). Like 'Alī, by shouting, he can destroy walls and doors (Sezen, 
1991: $76 \mathrm{v}-77 \mathrm{r})$. The narrator relates the astonishment and confusion of Hamza's enemies about his extreme heroic deeds, which he has accomplished despite his short height. Lendihā, for example, explains this apparent mismatch:

... Kīfāl Hindī introduced himself and asked: "O Lendihā, what kind of person is Hamza and how did he defeat you with this [short] height and make you his servant in spite of your strong muscles?" Lendihā replied: "Look, O brave [man], the skill is not in a tall height; power comes true through muscles. Hamza is not very tall, yet he is still the Șāhib-ḳırān ["The Master of the Auspicious Conjunction”] (Sezen, 1991: 14v).

As Lendihā's answer shows that while Hamza's height is not considered to be significant, his muscular body is considered to be an important feature of his heroic nature. Similarly, 'Ömer 'Ayyār, one of Hamza's great warriors, was a short, petit man. (Sezen, 1991: 68r). While Hamza and 'Alī are reported to have been short men, Bațtal is tall with an apparently muscular body (Battalname, 1996: vol. 1, 336). This variety in the physical appearances of the protagonists thus suggests that there was no fixed form that was used as a stencil for all Muslim heroic figures. This indicates that what is important, what makes a body a hero, is not the way that it looks, but rather the way that it functions. This emphasis on the functional use of the body is depicted clearly in two different versions of the story of Oğuz Kağan.

According to some scholars, the legendary Oğuz Kağan was the same person as Mete Hān (Mòdú Chányú, d. 174 BC), who is believed to have been the founder of the Hun Empire, itself popularly considered to be the first Turkic political entity in Central Asia. The Epic of Oğuz Kağan, which narrates the life story and adventures of Mete Hān, is therefore seen to be one of the earliest Turkish epics. Two short extracts from the story of Oğuz Kağan vividly demonstrate how much Islam, as a belief system, has influenced selfperceptions, and the extent to which it has shaped the self-understanding of men in different places and times.

We have three different versions of this epic. The first, which is in Uyghur Turkish and reflects the pre-Islamic narrative, describes Oğuz Kağan as follows:

Ay Kağan [his mother] gave birth to a green-eyed boy whose face was the sky, whose mouth was fire, and whose hair and eyebrows were black. He was more beautiful than even the good fairies. After sucking the first milk from his mother, he began speaking and asked for raw meat, soup, and wine. In 40 days, he grew up and began walking. His feet became like those of a bull, his belly like that of a wolf, his shoulders like those of a weasel. And his chest was as hairy as a bear. His body was covered with hair from the toe to the head (Bang vd., 1988: 13-14). 
The other two versions of the text reflect an Islamic interpretation of the epic. The description of our hero in the Cämi'ü't-Tevārīh (Compendium of Chronicles) of the thirteenth-century Ilkhanid historian, Rāşhidü'd-din Fażlu'llāh, offers a different set of details from the earlier story:

[Kara Han, the father] had a baby son who was worthy to be a sultan. Three days and nights, he did not suck his mother's breast. In the end, his mother lost all hope for the baby's life. [...] One night, she had a dream in which the baby said: "If you want me to suck your breast, declare the oneness of God..." She had the same dream for the following three nights. Yet, since she was of an infidel clan, she could not tell anything to anyone. Eventually, in secret from her husband, she declared the belief in one God. Then, she prayed to God, saying "Oh God, turn this poor one's milk into the taste this baby would enjoy." At that moment, Oğuz began drinking her milk immediately (Togan, 1972: 17).

Here, we can clearly see how the Islamification of the story re-defines its protagonist. While in the pre-Islamic version, the characteristics of wild and strong animals are attributed to the protagonist and his physically strong nature, in later versions it is his Islamic belief that becomes the essential feature. With Islam's monotheistic understanding of a single formless God, the hero's resemblance to nature is no longer tenable. The story demonstrates how Islam has influenced self- perception, bringing about a different understanding of the embodiment of heroism. In other words, how the owner of the body uses his body comes to matter more than the physical appearance of the body itself. This understanding of the body requires the active involvement of the body in physical fights. The hero has to take his body to the battlefield and physically face his rival/opponent in person. Success in physical fighting necessitates the hero being able to protect his body, which in turn requires him to obtain certain skills, such as shooting arrows, riding horses, throwing maces, and wrestling. Such skills require the kind of physical training that provides full control over one's body.

Of course, such skills alone does not make one a hero. Heroism is a state that can be reached through challenging, facing, and defeating an opponent, as the term ghazi (holy warrior) suggests. That is, no matter how brave or how skillful one is, he cannot obtain the honorific title of ghazi by sitting at home. Shooting arrows, riding horses, throwing maces, or wrestling are no more than performative shows when they do not make the person, who is decorated with these skills, successful in a physical struggle. Thus, Islamic heroic texts focus on a hero (male, of course,) who is always placed and portrayed in a fight with his enemies, whether they are human beings, wild animals, or supernatural powers. The protagonist is expected to defeat the other power by using his skills, his war tools, his riding prowess, and most importantly his body. The protagonist might 
be wounded during a challenging fight, but this would be considered a mark of his heroism; leaving a mark on the body of his opponent is considered a disgrace for that opponent.

It is important to note that heroism is legitimized only through the bodies of other (adult) male figures. Killing a woman or a child, marking their bodies with war wounds, or cutting off their body parts are not considered to be the signs of a hero. Legal texts on war laws indicate that hurting women and children during war is not acceptable. What makes the hero stand out among thousands of male warriors is the number of specifically male bodies that he cuts off or completely destroys. The more male bodies he damages, the more he is acknowledged as a hero. For example, in the Cenk-nāme, 'Ali is praised for the number of the male bodies [of his opponents] that he slaughters or cuts off during battle.

In case of death during a battle, what seems to be most significant is maintaining the integrity of the protagonist's body while deconstructing the integrity of his opponent. The Muslim heroes' martyrdoms are announced without details of what happened to their bodies. In the narratives relating their deaths, there are no legs and arms cut off or heads rolling on the ground, except those that belong to the protagonist's opponents. Being unable to maintain the integrity of their own body is a disgrace for early modern Islamic heroes. In the Șaltık-näme, Tül, the leader of the infidels in the story, loses his arm in battle. He is then offered the chance to have his body parts reunited if he converted to Islam by Șaltık:

O Tül! Be a Muslim; I will pray for you so that your arm may be attached to your body again, and you may become a full-bodied one with the grace of God (Demir and Erdem, 2007b: 171/T298-T299).

Șaltıḳ's proposal to Tūl demonstrates the significance of the body's integrity as well as the miraculous power of Saltık as a Muslim in the minds of medieval Muslims. If bodily strength, power, and integrity are critical for defining warrior-heroes, a different set of physical characteristics underscores the bodies of lovers.

\section{Love}

In Middle Eastern literature, love is structured as a triangle with three main figures: a lover, a beloved, and a rival. While the lover is most often either the poet himself or a poet-persona, the beloved could be the sultan, another person in a higher social position than the writer, or an actual beloved. The third figure in the love triangle is the rival, which could be either a person or a thing that obstructs the relationship between the lover and his beloved.

The bodies of the lover and beloved are described in detail, albeit in a clichéd form. Resembling the Huris in the Qur'an, the features of the beloved in 
lyrics, both female and male, represent a fixed and clichéd beauty, with a body like a cypress tree, black hair and eyes as dark as night, a round face like a full moon, small red lips as red and round as a newly blossomed rosebud, white skin as shiny as silver, white teeth as bright as pearl, and tiny facial peach fuzz (Ünlü, 2009; Gasimova, 2013a). There are no grammatical gender markers in Turkish that distinguish gender in the third person. Thus, the same metaphors and clichéd images of the bodies of the beloved, whether female or male, named or nameless, appear in ġazels (lyrics), mesnevīs (romances), hammämiyes (poetic forms dedicated to the features of a bathhouse and depictions of a beloved in a bathhouse), and the şehrengizs (romances dedicated to the beauties and beautiful girls and boys of a city).

This standardized beauty of the beloved is also repeated in depictions of the physical depictions of the lover in popular love stories, such as Leylä vü Mecnūn, Ferhād u Şirinn, and Yūsuf u Zuleyhā. Of these, Leylā vü Mecnūn is one of the most popular love stories in the Islamic world from the Caucasus to Africa and from the Atlantic to the Indian Ocean (Kuru, 2016). Leylā's fixed beauty features are also used for Mecnūn, the male protagonist of the story. When the two lovers first meet at school, their beauty is thus defined in similar terms: both have a stature and form that were divine creations; eyebrows as lovely as twins, forming one; eyelashes curving from their lids; black eyes; cheeks flushing red; a mole like a black pupil of sight; pearly white teeth; a round dimpled chin. Mecnūn's body is also described as a stately figure, cypress statured (Fuzûlî, 87/249-90/249).

Their two bodies, however, are not treated identically. While the body of the beloved is static and remains unchanged, the lover's body shows drastic changes as his love transforms him. When he is separated from Leylā, the healthy and beautiful body of Mecnūn turns into a weak, unhealthy, unattractive shape. He loses weight, his skin becomes pale, and even his bones can be seen due to his weakness. The impossibility of their love makes him wander in the desert, becoming friends with wild animals and birds. His hair becomes a matted nest for birds. The round, bloody wounds on his body, his pale skin, tiny and weak body, and tears running from his eyes demonstrate his pain and determination for love. (Fuzûlî, 130-131/262-263) (Figure 2) 


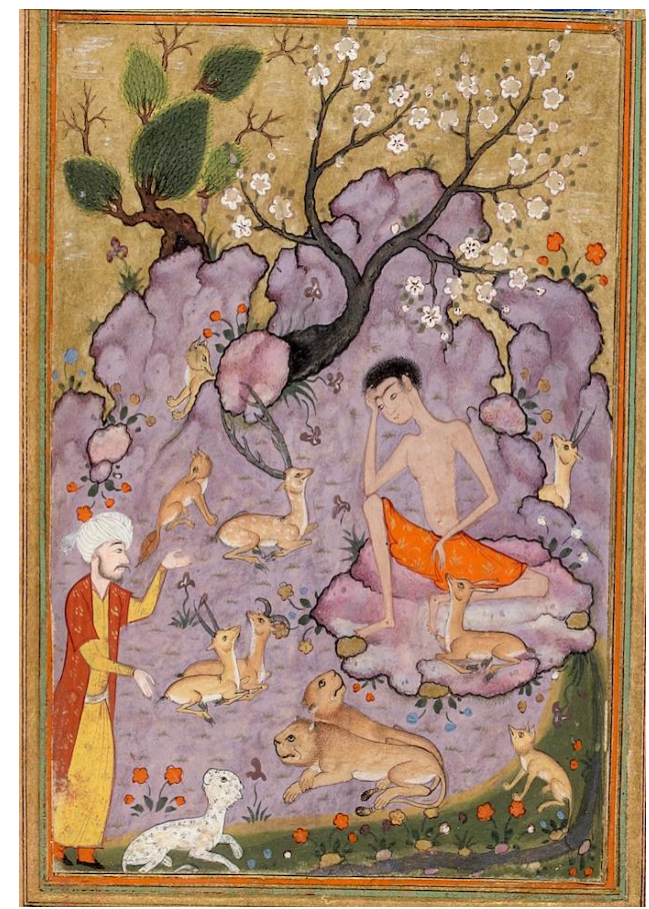

Figure 2. Fużūlī, Leylā vü Mecnūn, fol. 1v. Bibliothequé Nationale de France, Turc 316.

Mecnūn's deformed and ill body is highly idealized by the poets and used as an ideal form of the lover's body in the poetic tradition. It is identified with the Arabic letter däl ( $د$ ), which looks like a bent stick, suggesting that it is bent due to the pain of impossible love and physical weakness. The lover feels and physically embodies the pain of love. In the exaggerated images of poets, his wounds, constantly bleeding, cover his body and face. Due to their clichéd shapes, these wounds resemble red tulips, certain Arabic letters, and instruments of war. While the round wounds are equated with either red tulips, because of their color and shape, or the Arabic letter nūn ( $)$ ); the long wounds are symbolized by the letter elif ( 1 ), as the sixteenth century poet Bākī writes in the following couplet:

With love, cut [the letter] elifs on your chest

So everyone would know you love that cypress tree (Bâkî Dîvânı, 1994: 210/1)

Bākī repeats here the common literary symbol of the cypress tree, the symbol of the beloved's height due to its shape, along with the letter elif. The beloved, whose body resembles a cypress tree, opens wounds in the shape of 
the letter elif on the lover's body. These long cuts on the lover's body are imagined as having been opened by the beloved's eyelashes, eyebrows, and dimples, which are depicted in the romances, in turn, as sharp war tools, that is, daggers, knives, arrows, swords, and spears. In other words, the beloved's very features are re-imagined and described as murder weapons. The eighteenth century poet Rãsih's distich shows how eyelashes are depicted as soldiers lined up on the eyelids of the beloved, throwing arrows to the lover:

Don't let your eyelids droop so languorously that your eyelashes do not overlap

Don't shoot arrows on top of arrows at the wound of my chest (Akkaya, 2007)

The body of lover (poet) is also often depicted as a reed, which is perceived as a metaphor for the human being in the exegesis of Rumi's Mesnevi (Demirel, 2007). He is as thin as a reed, covered with round wounds like the holes on the reed. Furthermore, the reed's crying sound reminds the poet of the moaning that the lover makes for the beloved. A fine example of the body as a reed can be found in the words of the fourteenth century poet Kadı Burhāneddīn, who states "My body is like a reed" due to its wounds (Kadı Burhaneddin Divanı, 1980: Gazel 336/5; Zavotçu, 2009).

In Ottoman poetry, Bāṭini and Melāmī dervishes cauterized their chests as a means to tolerate the pain of love. These cautery wounds typically took the shape of a flower, most often a rose, although they could also represent the motif of fire, cosmic figures (i.e. the Sun and planets), different objects (i.e. a wineglass full of wine), or human body parts (i.e. lips). Once the wound started to heal and to scab, its color darkened. Its new shape and color then triggered the imagination of the poets, seeming to represent different flowers, objects, birds, or butterflies. In nomadic cultures, animals were cauterized with their owner's marks, in order to distinguish which animals belonged to whom. Over the time, the practice was also used to heal some diseases. Finally, it became a mark of lovers among the Bāțini and Melāmì dervishes who wanted to be noticed and distinguished for the pain of love that they experienced (Avşar, 2009).

Despite their similarities, then, what distinguishes the body of the lover from that of the beloved is the transformation of the lover's body. Love is seen to occur in the heart, but displayed on the body, similar to faith. While the lover's body is transformed into a weak form, no change appears on the body of the beloved. The beauty is the lover's, yet the deformation of the body symbolized the greatness of the lover's love. The beloveds remain beautiful, as if they are frozen in this physical form to keep them as the beloved. That is, beauty is the sign of the beloved, while a degenerated body is the sign of deep love. 


\section{Sexuality}

Even though sexuality does not seem to have been an explicitly discussed topic in early modern Islamic societies, we know that it was experienced colorfully and vividly in private, and that erotic jokes, poems, and illustrations were openly shared in some gatherings. ${ }^{15}$ What is significant for our purpose is that, to the early-modern physiognomists, one's high sex desire or lack of sexual desire is deemed to be just as traceable on the body as piety, holiness, heroism, and sinfulness. Mușțafá bin Bālī relates a story about a sultan famous for his piety who asks a talented artist to paint his portrait. The sultan then anonymously sends the portrait by courier to a highly knowledgeable physiognomist, iflimūn. Upon seeing the sultan's portrait, "based on the evidence and signs in the painting," iflimūn comments that the unnamed person in the painting is excessively lustful and inclined toward adultery. The courier interprets his words as ignorance and weakness in the science of physiognomy, and remains silent. When he conveys this interpretation of the painting back to the sultan, the sultan is highly surprised with iflimūn's skills in physiognomy. He then visits İflimūn and grants him gifts. The sultan eventually confesses that, "I am inclined to committing adultery, yet I protect myself from this fault with the help of God. Thus, this ugly fault does not happen to me." (Mustafa bin Bâlî, 2014: $164 / 27 v-28 r$ ).

The lesson to be taken from this story, according to our author, is that one should not assume immediately that the judgment made based on physiognomy books is wrong. One's natural inclinations, foretold by the physical nature of one's body, can be overcome with piety. On the other hand, the story is a clear evidence that, to physiognomy authors, certain characteristics on one's body reflect his/her sexual energy.

All genres discussed in this article thus far used the male body as a platform through which to discuss certain personality or spiritual features. Despite the existence of few texts dedicated solely to the physical appearance of women, such as a seventeenth century poet Enderūnlu Fāżll's Zenān-nāme ("The Book of Women") that describes the beauty and sexuality of women according to their race and where they are born, women are mostly absent from the literature. ${ }^{16}$ The female body does become visible in limited entries on sexuality in some physiognomy books. One should keep in mind that while much of the physiognomy literature avoids private body parts, those that pay attention to sexuality do not only discuss the male body. Even here, however, except for a few exceptions such as Şeyh 'Ömer Halvetī's Kıyäfet-nāme (1602) and İbrāhīm Haḳkı's Ma rifet-nāme (1757), there are almost no focused entries in the physiognomic manuals dedicated to the female body. The limited entries in

\footnotetext{
15 Recently, there has been extensive research on love, sexuality, and texts in an Ottoman context. See, for example, Schick, 2004, Andrews, \& Kalpaklı, 2005; Ze'evi, 2006; Kuru, 2007; Dalkıran, 2012; Anetshofer vd., 2016.

${ }^{16}$ Fāżıl-ı Enderūnī, Zenãn-nāme, British Library Or. 7094.
} 
the texts by íbrāhìm Ḥaḳk ınd Şeyh 'Ömer discuss how a sexually active female body can be understood, but do not trace a woman's personality based on her physical appearance (as they do for a man's). ${ }^{17}$ Yet, here too, erotic texts, generally known as Bah-nāmes, attempt to discern the hidden sexuality of women, paying attention to their sexual organs, rather than to the women's personalities. ${ }^{18}$ For example, detailed descriptions of the mouth, nose, chin, face, hair, and vagina are used to suggest the ability of a woman to give sexual pleasure to her partner:

There are such signs through which the degree of a woman's lust can be known. Wise people say that if a woman's mouth is big, her vagina is wide; if her mouth is small and narrow, her vagina is narrow. If her lower lip is fleshy, both sides of her vagina are fleshy; if her upper lip is thin, both lips of her vagina are as thin as filo dough. If her lower lip is thin, her vagina is dry. If the tip of her tongue is like a currant, her vagina is cold. If her nose is flat, she does not incline to intercourse. If the back of her arm is indented, she is very inclined to intercourse. If her hair is sparse, her vagina is shut. If her chin is long, her vagina is flat. If her face is big and fleshy, her vagina is big and it is favored to men. If her face is small, her vagina is small. If her face reddish and her eyes are blue, she is not lusty. If she laughs and moves a lot, she is lustful. If she enjoys dancing, she is lustful, if her upper legs are thin and ankles are big, her vagina is big. If her eyes are distinctive, her vagina is wide (Bardakçı, 2005). ${ }^{19}$

Clearly, as a vivid reflection of pre-modern pornography, these texts are not interested in a woman's personality, but only in the sexual benefits that could be obtained from her.

In physiognomy texts, sexual organs are "reproductive organs" or "tools," indicating that sex is perceived as an act that mainly facilitated procreation. They describe sexual organs as a means for the continuity of generations, as well as for satisfaction and joy. While the sexual organs are rarely mentioned, other individual body parts are used to diagnose the potential sexual performance of individuals. Excessive sexual desire and "the lack" of sexual desire can thus be diagnosed through individual body parts. According to

\footnotetext{
${ }^{17}$ On the şehrengiz literature, see ibid., "Sunuş," 7-23. See also, Selim S. Kuru, "Şehrengiz: Urban Rituals and Deviant Sufi Mysticism in Ottoman Istanbul." in Bulletin of the School of Oriental \& African Studies 79, no. 1 (2016): 190-192.

${ }^{18}$ On the Ottoman erotic literature, see İrvin Cemil Schick, "Representation of Gender and Sexuality in the Ottoman and Turkish Erotic Literature," The Turkish Studies Association Journal 28:1-2 (2004), 81-103; Tülay Artan and Irvin Cemil Schick, "Ottomanizing Pornotopia: Changing Visual Codes in Eighteenth-Century Ottoman Erotic Miniatures," Eros and Sexuality in Islamic Art, ed. Francesca Leoni and Mika Natif. Farnham: Ashgate, 2013, 157207.

${ }^{19}$ Quoted from an anonymous Bah-näme located in the private library of Murat Bardakçı. Murat Bardakçı, Osmanlı'da Seks Sarayda Gece Dersleri (Istanbul: İnkılap Kitabevi, 2005), 86-87.
} 
Muștafá bin Bălī, for example, the signs of excessive sexual desire are eyes similar to a lion, eyes similar to a goat, or small, bright, blue eyes; a face on which the right side is bigger than the left side; a hairy back or a hairy and curved back; a flat and stubby nose or a nose that falls over the face like a hose; deep voice or a very high voice; a fleshy neck; a long and large molar tooth; a goatee beard; large hands covered with long hair and hairy wrists or large hands and protruding knuckles and fingers with hair; flat and long fingers; and a bumpy head. By contrast, the signs of a lack of sexual desire were "very thick eyelids" and "excessive beauty spots on the face and body."

While the male member, which is often ignored, represents masculinity in only a few texts, more importance is accorded to the other parts of the male body. For example, an extremely large sexual organ is a sign of strength and excessive desire for sexual acts, while an extremely small one indicates impotence and lack of desire for sex. While in most cases individual body parts are compared to each other, male to male, there are rare exceptions. For example, Muștafá bin Bāli constructs the male body and its sexuality by comparing it to the female body. Strength defines masculinity and thus sexuality, and so therefore the male body's relatively larger size is a definitional element of a man. His gendered perceptions create a certain idea of sex, based on what he calls evidence:

First evidence: Men's bodies are tight; their eyes and nerves are strong; their feet are big and coarse; and their faces and skin are less beautiful than women. Second evidence: Men's appetites are immense and their digestion is adequate [to their eating habits]; and their tolerance for movement and difficulties is high. Third evidence: Men's pulses are strong and big. They have considerable bravery, effort, and wrath. Fourth evidence: Men are better than women in beauty of mind, contemplation, and obtaining knowledge. Fifth Evidence: Men are more generous and moral than women (Mustafa bin Bâlî, 2014: 359-360/53v-54r).

All of these physical characteristics point to a man's inherent sexuality. Mușțafá bin Bālī also offers evidence for being a woman:

First Evidence: Women's bodies are loose and fleshy. Their thighs are rounded (fleshy), their faces are thin; their breasts are weak; their ribs are thin and small; even their feet are thin. Besides, the flesh that covers the nerves is "humid," and even their nerves are soft. Second evidence: The females of all species have small heads. In addition, their hips and thighs are rounded (fleshy). And their calves are thick. Third evidence: Women are silent, and they don't move a lot. Their souls are not stubborn, strong, or violent. Thus, they are easy to control. Fourth evidence: Their anger and inclination for revenge is small. However, they have many tricks, and they cross 
boundaries. These are the signs of their weak personalities. Fifth Evidence: In terms of humanly acts and good personality, they are lacking (Mustafa bin Bâlî, 2014: 360/54r).

The text constructs masculinity and maleness in relation to the body by imagining manliness as a result of muscularity and body size, which in turn not only indicates a certain kind of sexuality, but also better intellectual and moral values than one could find in a lesser "manly man" or in a woman.

\section{Conclusion}

The human body remains at the center of attention in Islamic tradition, as worship is still a combined experience of body and soul. The article has demonstrated the various ways that the body was used as a platform on which, and through which, certain values could be displayed in Islamic tradition as well as Ottoman literature. As we have seen, while legal texts understand the body as a mirror that reflects one's piety and/or sinfulness in both this world and hereafter, literary genres have perceived the human body as a mirror through which one's good or bad personal traits, faith, sanctity, and heroism, as well as depth of love and capacity for sexuality, could also be physically witnessed.

Each of these genres offers its own focus in creating its own world. For example, while the texts of the kısșașu'l-enbiyā focus on stories of the Prophet Muhammed and other prophetic figures, the gazavāt-nāme or cenk-nāme texts focus on heroic stories of post-Islamic warrior figures, and the mesnevīs center on their protagonists' passion for their beloveds. The physiognomy texts, for their part, trace personality features in accordance with a person's bodily features. In each case, the physical, tangible body takes center stage as a means to perceive, evaluate, and judge the person inside of it.

While these genres, and others, have been studied either with a focus on their creators or the texts they encompass, we should not neglect the vigorous interaction that takes place between them. Even though the miraculous stories and exemplary personalities of the prophets are the emphasis of the kıșașu'lenbiya texts, such figures are employed in panegyric (kașide) forms to establish a standard form for their patrons. Comparative studies between genres would help us see how different genres converse with each other and complete each other like the pieces of a puzzle. The consequences of piety, for example, are transferred from legal texts to the mi räc-nämes, as we have seen in the fifteenth century anonymous Persian mi 'rāc-näme of a Herati scholar. Likewise, the notable features of heroic figures are moved to the panegyric poetry to praise a ruler. What is most striking in relation to this study is that all of these genres use the human body as a platform to make their points tangible for their audiences. In fact, except a few rare texts, they almost exclusively use the male body to make their argument. 
The reason for employing only the male body is, of course, the concept of mahremiyet (privacy) of women in the Islamic tradition that requires hiding the female body from the public. However, women's most private bodily organs are discussed in detail by some physiognomists who describe them, making them quite visible through their words. Even though one cannot argue that early modern writers only perceived the female body as a sexual object, it is significant that the only way that women were made truly visible was through their sexuality and their ability to procreate. Then, as now it seems, women's bodies were not their own to do as they wished.

\section{Bibliography}

Akkaya, H. (2007). Râsih Bey'in 'üstine' redifli meşhur gazelinde ikilemelerin kullanılıșı. Turkish Studies/Türkoloji Araştırmaları, (2)3, 25-31.

Andrews, W. G., \& Kalpaklı, M. (2005). The age of beloveds: Love and the beloved in early-modern Ottoman and European culture and society. Chapel Hill: Duke University Press.

Anetshofer, H. N., Hüner-cora, I., \& Schick, I. C. (2016). Cinsel içerikli bir Osmanlı kıyâfetnâmesi: Ta'rîfnâme-i zenâne. Toplumsal Tarih, (270), 28-37.

Artan, T., Schick, I. C. (2013). Ottomanizing pornotopia: Changing visual codes in eighteenth-century Ottoman erotic miniatures, F. Leoni \& M. Natif, Eros and Sexuality in Islamic Art (157-207). Farnham: Ashgate.

Al-Ashqar, 'U. S. (2002). The final day paradise and hell in the light of the Qur'an and Sunnah (N. al-Khattab, Trans.). Riyadh: International Islamic Publishing House.

Al-Ashqar, 'U. S. (2005). The final day the day of resurrection in the light of the Qur'an and sunnah (N. al-Khattab, Trans.). Riyadh: International Islamic Publishing House.

Aramesh, K. (2009). The ownership of human body: An islamic perspective. Journal of Medical Ethics and History of Medicine, (2)4. Retrieved from https://www.ncbi.nlm.nih.gov/pubmed/23908718

Avşar, Z. (2009). Âşığın bedeninin göstergesi: Dağlama. In E. Gürsoy Naskali \& A. Koç (Eds.), Ĭğdiş, sünnet, bedene şiddet kitabı (pp. 167-182). Istanbul: Kitabevi.

Bahkou, A. (2015). The monk encounters the prophet-The story of the encounter between Monk Bahira and Muhammad as it is recorded in the Syriac manuscript of Mardin 259/2. Cultural and Religious Studies, (3)6, 349357.

Bâkî Dîvânı. (1994). (S. Küçük, Ed.), Ankara: Türk Dil Kurumu.

Bang, W., Ergin, M., \& Arat, R. R. (1988). Oğuz Kağan destanı. Ankara: Hülbe.

Bardakçı, M. (2005). Osmanlı'da seks sarayda gece dersleri. Istanbul: İnkılap.

Barlas, A. (2002). "Believing women in Islam" Unreading patriarchal interpretations of the Qur'an. Austin: University of Texas Press.

Bashir, S. (2011). Sufi bodies: Religion and society in medieval Islam. New York: Columbia University Press. 
Battalname: Giriş, Ingilizce tercüme, Türkçe metin, yorum ve tıpkıbasım (Y. Dedes, Ed.), (1996). [Cambridge, Mass.]: Harvard Üniversitesi Yakındoğu Dilleri ve Medeniyetleri Bölümü.

Bigotti, F. (Forthcoming, 2019). Physiology of the soul: Mind, body, and matter in the Galenic tradition of the late renaissance (1550-1630). Turnhout: Brepols.

Callard, F. J. (1998). The body in theory. Society and Space, (16)3, 387-400.

Celāle'd-dīn Suyūtī. (1997). Reşfü’z-zülāl mine's-siḥri'l-ḥelāl. Beirut: Mua'ssasa alIntishar al-Arabi.

Cunbur, M. (1987). Anadolu gazileri ve edebiyatımız. Erdem, (3)9, 777-807.

Çakır, M. (2007). Kıyâfet-nâme'ler hakkında bir bibliyografya denemesi. Türkiye Araştırmaları Literatür Dergisi, (5)9, 333-350.

Çavuşoğlu, A. (2004). Kıyafetnameler. Istanbul: Akçağ.

Dalkıran, A. (2012). On yedinci yüzyıl Osmanlı minyatürlerinde sıra dışı bir eğilim: Müstehcenlik. İdil, (1)5, 112-131.

Dasen, V. (2015). Body marks - Birthmarks. Body divination in ancient literature and iconography. In A. Shapiro et al. (Eds.). Bodies in transition: Dissolving the boundaries of embodied knowledge (pp. 155-177). Munich: Morphomata,

Demir, N., Erdem, M. E. (2007a). Hazret-i Ali cenkleri. Ankara: Destan.

Demir, N., Erdem, and M. E. (2007b). Saltık-nāme I-II-III. Ankara: Destan.

Demircan, A., Keskin, Y. Z. (2009). İslam'da bedene işkence yöntemi olarak müsle. In E. G. Naskali \& A. Koç (Eds.), İğdiş, sünnet, bedene şiddet kitabı (pp. 49-64). Istanbul: Kitabevi.

Demirel, Ş. (2007). Mesnevî'nin Türkçe şerhlerinde ney metaforu. Türk Kültürü, Edebiyatı ve Sanatında Mevlâna ve Mevlevîlik - Bildiriler 1(1), 149-192.

Çakır, M. (2007). Kıyâfet-nâme'ler hakkında bir bibliyografya denemesi. Türkiye Araştırmaları Literatür Dergisi, (5)9, 333-350.

Enverī. (2017). Kıyāfetnāme numūne-i Enverī. (B. Direkçi \& H. Duyar, Eds.), Konya: Palet.

Enverî. (2018). Kıyâfet-nâme (B. Elbir, Ed.), Istanbul: Doğu Kütüphanesi.

Fāżıl-ı Enderūnī. Zenān-nāme. British Library Or. 7094.

Foucault, M. (1979). Discipline and punish the birth of the prison. (A. Sheridan, Trans.). New York: Vintage Books a Division of Randomhouse, Inc.

Fużūlī. Leylā vü Mecnūn. Bibliothèque Nationale de France, Turc 316.

Fuzûlî. (1981). Leylâ vü Mecnûn. (H. Ayan, Ed.). Istanbul: Dergâh.

Gasimova, A. S. (2013a). The hair on my head is shining: Qur'anic imagery of the curl in classical Azeri-Turkish șūfī poetry. Journal of Qur'anic Studies, 15(1), 69-101.

Gasimova, A. S. (2013b). Eyebrows in Islamic images and ideas. In J. A. Morrow (Ed.), Essays on sacred symbolism (pp. 169-183). North Carolina: McFarland.

Giles, J. (1991). Bodily theory and theory of the body. Philosophy, (66)257, 339347.

Gruber, C. (2009). Between logos (kalima) and light (nur): Representations of the prophet Muhammad in islamic painting. Muqarnas (26), 229-262. 
Hafidh Abi Al-Fada'ah Ismail ibn Kathir. (2001). Book of evidences: The miracles of the Prophet (p. b. u. h.) (A. M. Mzima and Ibn. R. Ramadhan, Trans.). AlMansoura: Dar al-Gad.

Halevi, L. (2007). Muhammad's grave death rites and the making of Islamic society. New York: Columbia University Press.

Hilye-i Nebeviyye. TSMK, H 1251.

Hindî Mahmûd. (2013). Kısas-ı enbiyâ peygamber kıssaları inceleme-tenkitli metintıpkı basım. Istanbul: Türkiye Yazma Eserler Kurumu Başkanlığı.

Hoffman, V. J. (1995). Islamic perspectives on the human body: Legal, social and spiritual considerations. Embodiment, Morality, and Medicine. Theology and Medicine Book Series, (6), 37-55.

Hospers, J. (1967). An introduction to philosophical analysis (2nd ed.). London: Prentice Hall.

İmam Ebû'l-Hasan el-Mâverdî. (1976). El-ahkâmu's-sultâniyye isılâm'da hilâfet ve devlet hukuku. (A. Şafak, Trans.). Istanbul: Bedir.

Imam Imaduddin Abdul-fida Isma'il ibn Kathir Ad-Dimashqi. (2003). 700-774H, stories of the prophets (Peace be upon them), (Rashad Ahmad Azami, Trans.). Darussalam: Riyad.

Kadı Burhaneddin divanı (1980). (M. Ergin, Ed.). Istanbul: Edebiyat Fakültesi.

Kazuyo, M. (2017). Beauty in Islam teachings of Rūzbihān Baqlī. Albany: Suny.

Khuri, Fuad I. (2001). The body in Islamic culture. London: Saqi Books.

Kister, M. J. (1994). '... and he was born circumcised...': Some notes on circumcision in hadīth. Oriens (34), 10-30.

Kitābü'l- menāmāt. Nuruosmaniye, nu. 2599.

Kitābu'l-menāmāt: Sultan III. Murat'ın rüya mektupları. (2014). (Ö. Felek, Ed.). Istanbul: Tarih Vakfı Yurt.

Köksal, H. (1984). Battalnâmelerde tip ve motif yapısı. Ankara: Kültür ve Turizm Bakanlığı Milli Folklor Araştırma Dairesi.

Kugle, S. (2007). Sufis and saints' sodies: Mysticism, corporality, and sacred power in Islam. Chapel Hill: The University of North Carolina Press.

Kuru, S. S. (2007). Sex in the text: Deli Birader's Dāfi'u'l-gumūm ve Rāfi'u'lhumūm and the Ottoman literary canon. Middle Eastern Literatures, (10)2, 157-174.

Kuru, S. S. (2016a). Naming the beloved in Ottoman Turkish gazel: The case of İshak Çelebi (D. 1537/8). In Angelika Neuwirth, Michael Hess, Judith Pfeiffer, Börte Sagaster (Eds.), Ghazal as world literature II: From a literary genre to a great tradition the Ottoman gazel in context (pp. 163-173). Würzburg: Ergon Verlag.

Kuru, S. S. (2016b). Sehrengiz: Urban rituals and deviant sufi mysticism in Ottoman Istanbul. Bulletin of the School of Oriental \& African Studies, (79)1, 190-192.

Lange, C. (2007). 'On that day when faces will be white or black' (Q3:106): Towards a semiology of the face in the Arabo-Islamic tradition. Journal of the American Oriental Society, (127)4, 429-445. 
Lange, C. (2016). Paradise and hell in Islamic traditions. New York: Cambridge University Press.

Lelic, E. (2017). Physiognomy ( 'ilm-i firāsat) and Ottoman statecraft: Discerning morality and justice. Arabica, (64), 609-646.

Lennon, K. (2014). Feminist perspectives on the body. In The Stanford Encyclopedia of Philosophy Edward N. Zalta (Ed.). Retrieved from URL

$=<$ https://plato.stanford.edu/archives/fall2014/entries/feminist-body/>.

Menâkıb-i Hazret-i Üftâde. (1996). (A. Yünal, Ed.). Bursa: Celvet.

Mustafa bin Bâlî. (2014). Risâle-i kiyâset-i firâset ilm-i firâset \& yüzler hâli söyler mizaçlar, huylar, uzuvlar, dimağ, kalp, insanın dönemleri, insan türlerinin ahlâkı, ırklar, beldeler, mekânlar ve iklimler...inceleme-günümüz Türkçesimetin-tıpkıbasım. (R. Sarıçiçek, Ed.). Istanbul: Büyüyen Ay.

Oymak, i. (2013). Harput'ta bulunan kutsal mekânlar ve inanç turizmi açısından değerlendirilmesi. Fırat Üniversitesi Harput Uygulama ve Araştırma Merkezi Geçmişten Geleceğe Harput Sempozyumu, Elazığ 23-25 May 2013.

Özarslan, S. (2006). Peygamberlerin özelliklerinden erkek olmak ve düşündürdükleri. Cumhuriyet Üniversitesi IIlahiyat Fakültesi Dergisi, $(X / 2)$, 109121.

Renard, S. J., (1993). Islam and the heroic image: Themes in literature and the visual arts. Columbia: South Carolina UP.

Renard, S. J., (1985). Heroic themes in medieval islamicate art and literature. Journal of the Journal of Sophia Asian Studies, (3), 167-189.

Richardson, K. (2012). Difference and disability in the medieval islamic world: Blighted bodies. Edinburgh: Edinburgh University Press.

Richardson, K. (2014). Blue and green eyes in the islamicate middle ages. Annales Islamologiques, (48)1, 13-29.

Rubin, U. (1975). Pre-existence and light. Israel Oriental Studies, (5), 62-119.

Schick, i. C. (2004). Representation of gender and sexuality in the Ottoman and Turkish erotic literature. The Turkish Studies Association Journal, (28:1-2), 81103.

Schick, i. C. (2007-9). Some islamic determinants of dress and personal appearance in southwest Asia. Khil'a, (3), 25-53.

Schick, ì. C. (2017). Hûbân-nâme-i nev-edâ. Bir İstanbul esnaf güzellemesi. Istanbul: Kalem ve Hokka.

Seyyid Loḳmān Çelebi. (1987). Kıyāfetü’l-insāniyye fi şemāili'l-'osmāniyye. Istanbul: Historical Research Foundation, Istanbul Research Center.

Sezen, L. (1991). Halk edebiyatında hamzanâmeler. Ankara: Kültür Bakanlığı.

Swain, S. (2007). Seeing the face, seeing the soul. Polemon's physiognomy from classical antiquity to medieval Islam. With contributions by Boys-Stones George, Elsner Jas, Ghersetti Antonella, Hoyland Robert and Repath Ian. Oxford: Oxford University Press.

Şemseddin Sivasi. (2017). Menâkıb-ı çehâr-yâr-ı güzin (M. Arslan, Ed.). Istanbul: Şemseddin Sivasi Külliyatı.

Ta'likîzâde M. S. (2016). Firâset-nâme (M. Gürbüz, Ed.). Ankara: Grafiker. 
Tarlan, A. N. (1964). Şeyhi divanı'nı tetkik. Istanbul: İstanbul Üniversitesi Edebiyat Fakültesi.

The life of Muhammad a translation of Ishāà's Sirat Rasūl Alläh with introduction and notes by A. Guillaume. (2012). Lahore, Karachi: Oxford University Press, Pakistan Branch.

The miraculous journey of Mahomet Mirâj Nâmeh Bibliothèque Nationale, Paris (Manuscrit Supplement Turc 190) Introduction and Commentaries by MarieRose Séguy. (1977). New York: George Braziller.

Togan, A. Z. V. (1972). Oğuz destanı Reșideddin Oğuznâmesi, tercüme ve tahlili. Istanbul: Ahmet Sait Matbaası.

Ulu, A. (2012). Âdet halindeki kadının orucuyla ilgili hadislerin tenkid ve tahlili. Atatük Üniversitesi Ilahiyat Fakültesi Dergisi, (38), 1-50.

Ünlü, O. (2009). Klâsik Türk edebiyatında erkek güzelliği ve erkek aşkı anlayışı: Cinânî örneği. Kritik Edebiyat Eleştrisi Dergisi, 17-48.

Velâyetnâme Hacı Bektâş-ı Veli. (2007). (H. Duran, Ed.). Ankara: Türkiye Diyanet Vakfı.

Zavotçu, G. (2009). Ney’in öyküsü ve dîvân şiirinde işlenişi. A. Ü. Türkiyat Araștırmaları Enstitüsü Dergisi Prof. Dr. Hüseyin Ayan Özel Sayısı, (39) 719-751.

Ze'evi, D. (2006). Producing desire: Changing sexual discourse in the Ottoman middle east, 1500-1900. Berkeley: University of California Press. 